\title{
AZ ÉPÍTÉS - ÉPÍTÉSZETTUDOMÁNY FOLYÓIRAT 60 ÉVÉRŐL
}

\author{
VÁMOSSY FERENC \\ az MTA doktora, professor emeritus, az Épités - Épitészettudomány szerkesztője. \\ BME Építészettörténeti és Múemléki Tanszék. Tel.: (+36-1) 316-3877
}

\begin{abstract}
A Szerző, mint az Épités - Épitészettudomány (rövidítve ÉÉT, korábban Épittés- és Közlekedéstudományi Közlemények, rövidítve ÉKTK) szerkesztőségének 1957-től munkatársa, visszatekintésében a Mủegyetem mérnöki és építészmérnöki karának tudományos-szellemi életét szolgáló folyóirat történetét, feladatait és azoknak teljesítését kívánja megvilágítani. Arra törekszik, hogy a lap saját belső fejlődésén túl a korabeli tudományos kutatás egészéről is képet nyújtson. Erre lehetőséget ad az is, hogy a lapban 2007-ben az 1957-2007 közötti éveket három nyelven (angolul és németül is) összefoglaló tartalomjegyzék és a fö munkaterületeket elemzö, alapos értékelő tanulmány jelent meg négy szakértő részéröl.

Az ÉKTK korszaka (1957-1968) még szélesebb szakterületet ölelt fel, az akadémiai kutatás tudományterületeinek kiépülési időszakát. Az ÉÉT időszakában 1969-től az elméleti és alkalmazott mechanika és az építés közös területe jelenti a mérnöki szakterületet, míg az építészettudomány, építészettörténet és múemlékek, illetve a településtudomány a másikat. Sajátos változást jelentett a 2000. év a lap előállításában s így szerkesztésében is azzal, hogy beköszöntött a digitális korszak. A belső, egyetemi változások, így a doktori iskolák megjelenése és más intézményi változások már előbb, az 1990-es években éreztették hatásukat.

A szerző cikkében összefoglalja a négy szakértő 2007-ben írt legfontosabb megállapításait. Marosi Ernő művészettörténész az építészettörténet, a műemlékek és az építészetelmélet kapcsolatát elemezte, és a lap mủvészettörténeti jelentőségét méltatta. Gáspár Zsolt, a szerkesztőbizottság tagja 50 év minden szerzőjét és tanulmányát mérlegre téve elemezte a mechanika tudomány belső fejlődését és újabb fejezeteinek kibontakozását. Finta József az alkotó-tervező oldalról szemlélte a lapot és vizsgálta szerepét a tervező építészi szemlélet hazai kialakulásában. Meggyesi Tamás a településtudomány, településtervezés és urbanisztika nézőpontjából tekintette át a közölt tanulmányokat és méltatta a lap szerepét témakörében. A szerző végül saját szerepét és felelősségét veti fel a Szerkesztőség életében. Legfontosabb eredményként a szerzőgárda kialakulását és a szerkesztői tevékenységben érzékelhető együttmüködést említi, tekintettel arra, hogy visszavonulásával lezárul 60 éves szolgálata.
\end{abstract}

Kulcsszavak: szerkesztőség, tudományos-szellemi élet, tudományterület, együttmüködés

\section{AZ ÉPÍTÉS- ÉS KÖZLEKEDÉSTUDOMÁNYI KÖZLEMÉNYEK KORSZAKA (1957-1968)}

A Magyar Tudományos Akadémia Müszaki Tudományok Osztálya által 1957-ben alapított folyóirat I. kötete az alábbi bibliográfiai adatokkal jelent meg:

Épités- és Közlekedéstudományi Közlemények. A Magyar Tudományos Akadémia Müszaki Tudományok Osztályának keretében müködő Építéstudományi, Építészet- 
történeti és Elméleti, Építőanyagtudományi, Hidrológiai és Vízgazdálkodási, Közlekedéstudományi és Településtudományi Bizottság közlönye. Főszerkesztő: Mihailich Győző. Szerkesztő: Major Máté. Szerkesztőbizottság: Czére Béla, Gábor László, Granasztói Pál, Gyengő Tibor, Király Jenő, Lászlóffy Woldemár, Major Máté, Pogány Frigyes, Reischl Antal. I. kötet, 1-2. szám. Budapest 1957.

1960-ban már történt változás, a teljes szöveg: Épités- és Közlekedéstudományi Közlemények. A Magyar Tudományos Akadémia Müszaki Tudományok Osztályának keretében müködő Építéstudományi, Építészettörténeti és Elméleti, Hidrológiai és Vízgazdálkodási, Közlekedéstudományi és Településtudományi Bizottság közlönye. Főszerkesztő: Mihailich Győző. Szerkesztő: Major Máté. Szerkesztőbizottság: Bonta János, Czére Béla, Gábor László, Granasztói Pál, Lászlóffy Woldemár, Major Máté, Pogány Frigyes, Szabó János. Technikai szerkesztő: Vámossy Ferenc. IV. kötet, 1-2. szám. Budapest 1960.

Bár történtek változások, mint Mihailich Győző halála s egyes szerkesztőbizottsági tagok kimaradása miatt korábbiak a módosulások, csak 1965-ben változott a szöveg: Épités-és Közlekedéstudományi Közlemények. A Magyar Tudományos Akadémia Müszaki Tudományok Osztályának keretében müködő Építéstudományi, Építészettörténeti és Elméleti, Hidrológiai és Vízgazdálkodási, Közlekedéstudományi és Településtudományi Bizottság közlönye. Főszerkesztő: Major Máté. Szerkesztőbizottság: Bonta János, Czére Béla, Gábor László, Granasztói Pál, Lászlóffy Woldemár, Major Máté, Pogány Frigyes, Szabó János. Technikai szerkesztők: Horváth Tiborné, Vámossy Ferenc. IX. kötet, 1. szám. Budapest 1965.

A lapszerkesztés munkáiba 1957-ben, Major Máté tanszékén, az ő megbízásából az első szám összeállítása idején kapcsolódtam be, öt év tervezői szakmai gyakorlat után azzal az ambícióval, hogy a Budapesti Müszaki Egyetem két karának, az Építőmérnöki és Építészmérnöki Karnak korabeli tudományos életét az azokat képviselő szerkesztőbizottsági tagok irányításával szolgáljam. Ehhez az általam nem ismert témák esetében is rendkívül komoly eligazítást és támogatást kaptam. A szerkesztőbizottság üléseiről részletes jegyzőkönyveket állítottam össze, és feladataim végzéséhez volt professzorom, Csonka Pál tevékenységét tekintettem példának, aki az Osztály angol nyelvü lapjának, az Acta Technicának a teendőit vállalta 70 évesen magára. Számomra ez a betanulás és beilleszkedés időszaka volt, amihez adottságaim és alapképzettségem, volt tanáraim és a szerkesztőbizottsági tagok elegendő eligazítást nyújtottak. A szerkesztőbizottság aktív működése jellemezte a korszakot, az Épités- és Közlekedéstudományi Közlemények (rövidítve: ÉKTK) ekkori 12 kötetének megvalósulását, amelyben 1965-től a technikai szerkesztőmunkát már ketten, Horváthné Sipos Edithtel együtt végeztük. Ez a korszak tudományos szempontból az Akadémia és a tudományok intézményrendszere 1950-es évek eleji újjászervezése után az 1957 utáni kibontakozás, a müszaki tudományokon belül pedig az új technikai, technológiai és szervezési módszerek kibontakozásának és modernizációjának az időszaka volt. 
A hazánkra erőszakolt államszocializmus célja a társadalom teljes átalakítása révén a szocialista, illetve kommunista társadalom alapjának a megteremtése volt. A cél alkalmasnak vélt eszköze az erőszakosan felgyorsított modernizáció. Ezt szolgálta a társadalom és a gazdaság intézményeinek központosítása, anyagi és szellemi folyamatainak ellenőrzése, a társadalom életének és a termelés minden részletének szabályozása, a minden más gondolatrendszert elutasító ideológiai nyomás és a tervgazdaság kényszerrendszere.

A tervgazdaság kényszerrendszerének hazai megvalósulásában az 1956-ot követő káosz és megtorlás esztendeit a hatvanas évek elején bekövetkező társadalmi konszolidáció és az építészet 1960-1965 közötti megújulása követte. 1965 után ugyan a gazdaságban ismét a lassulás válságjelei jelentkeztek, és míg az építészetben folytatódik a megújult szemlélet talaján a továbblépés, politikai döntések alapján kényszerítő erőfeszítéssel megindul az építésiparosítás, a házgyárak telepítése és a mechanikus elvekre épülő lakásépítés. A hatvanas évek építészetében jelentős értékek is születtek, amelyek egyes vonásaikban a nyugat-európai folyamatokhoz való igazodást jelentik a viszonylagos nyitás érzékelhető jeleként. A salgótarjáni központ, melynek ihletője Le Corbusier késői vasbeton építészete, Kenzo Tange 1964-es tokiói olimpia együttesének idején valósult meg, jelezve a hazai törekvések időszerüségét.

1968 korszakhatár a közép-európai fejlődésben, amely jól tükröződik a folyóirat első tíz évének történetében is. Lapunk addig müködött tartalmában szélesebb keretben, amíg ez nem akadályozta túlzott bőségével alapvető céljaink megvalósítását.

Az 1957-1965 közötti időszakban megerősödött a szaktudományi élet azoknak a bizottságoknak a területén, amelyek a lap müködésével kaptak szélesebb lehetőséget a publikálásra. Különösen jelentős volt azoknak a konferenciáknak a publikálása, amelyek a kor aktuális problémáival foglalkoztak és az állami vezetés számára is fontosak voltak, összegezésükkel segítették a gyakorlatban megvalósulásukat. Az építéstudományok területén a II. kötet 1. számában jelent meg $A z$ 1957. évi Elöregyártási ankét, a Mélyépítési tagozat és a Magasépítési tagozat üléseinek teljes számot betöltő anyaga. A 2. számban a Közlekedéstudományok Bizottsága területén az Országos közúti ankét, a 3-4. számban az Épitészettörténeti és Müemléki Konferencia teljes anyaga olvasható, míg a VI. kötet 2. száma az Ipari épitési konferenciával foglalkozott. A IV. kötet 3. száma már a II. Épitészettörténeti és Müemléki Konferencia nemzetközi jelentőségü anyagát közölte, miközben az I-VI. kötet többi száma is különböző tudományos területek igen fontos cikkeit, szemleanyagait és könyvismertetéseit publikálta. Olyan fontos témák szerepeltek ezekben, mint $A$ többtámaszú vasbetontartók új elmélete (I. 3-4.), A magyarországi regionális tervezés alapjai (IV. 1-2.), Müemléki együttesek védelmének irányelvei (IV. 3.), Nagyvárosok közlekedése (IV. 4.), A vasutak épitészete Európában (V. 1-2.), A modern urbanisztikai szemlélet, épitészeti megvilágitásban (V. 3.), A Bauhaus - eszme és valóság, valamint $A$ Bauhaus mühelyei (VI. 4.). A szigorúan müszaki tudományterületek számtalan fontos, többnyire laboratóriumi eredményekkel is foglalkozó cikkét itt nem említem, csak a Szemle rovatokban közölt szaktudományi beszámolókra és át- 
tekintésre hívom még fel a figyelmet, hogy a témakörök fejlödését tudományterületünkön említhessen.

Az 1960-as évek kibontakozása 1963-tól jól követhető a VII-XII. kötet tartalomjegyzékeiből, amit az Épités - Épitészettudomány 35. kötetének 3-4. számában, 2007-ben Repertóriumként, a múltra történő visszatekintésként összefoglaltunk. 1965-től már ketten végeztük a kötetek elökészítését, nagyobb figyelemmel még igényesebbé válhatott a tanulmánykötetek illusztrálása is.

E korszak fontos konferenciaanyagai a VIII. kötet 1-2. számában megjelent Történeti városok fejlesztése - épitészettörténeti kérdések címü témakörben tartott A „Városépitéstörténet és épités történeti városokban” c. akadémiai munkaközösség IV. nemzetközi konferenciája és A III. Épitészettörténeti és müemlékvédelmi konferencia együttes anyaga, továbbá a X. kötet 1 . számában az MTA Nemzetközi müemlékvédelmi munkaértekezlet. A VI. kötet 4. számában megjelent Településtudományi kandidátusi viták hatására rendszeressé vált a viták anyagának közlése is, érzékelhetö a Településtudományi Bizottság aktívabbá válása. Az Épités- és Közlekedéstudományi Közlemények címü folyóirat utolsó száma, a XII. kötet 3-4. szám 1968-ban jelent meg.

Ennél az első időszaknál meg kell említenem, hogy bár alacsony példányszámban jelent meg a folyóirat, de az ekkoriban igen fontos új állami intézményrendszerben jelen volt, és a korabeli publikációs igényt kielégítette. Szerzőinek és olvasóinak rétege a szaktudományainak széles körét felölelte, a tudományfejlesztés feladatait az elvárható mértékben betöltötte. Tizenkét éves időtartama alatt természetes módon alakult ki az az igény, hogy a müködő folyóirat tudományterülete beszüküljön és saját szükebb területére koncentrálja erőforrásait. Ekkorra, az 1960-as évek végére az ipari háttér és az azt irányító tervezöirodai rendszer kiépült; a szakterületet szolgáló tudományos kutatás intézményrendszere jelentősen megerősödött. Az Akadémia Müszaki Tudományok Osztálya átszervezhette folyóiratait, az Épités-és Közlekedéstudományi Közlemények szerkesztőségére építve hozta létre Epités- Épitészettudomány címmel megújult folyóiratát.

\section{AZ ÉPÍTÉS- ÉPÍTÉSZETTUDOMÁNY FOLYÓIRAT INDULÁSA ÉS KORSZAKAI}

Az Épités- Épitészettudomány (rövidítve: ÉÉT) I. kötet 1-2. számában (1969) a folyóirat az alábbi bibliográfiai adatokkal jelent meg, s így ezzel kezdődik a folyóirat új korszaka:

Épités- Épitészettudomány. A Magyar Tudományos Akadémia Műszaki Tudományok Osztályának közleményei. Szerkeszti: Major Máté. Szerkesztőbizottság: Gábor László, Kaliszky Sándor, Kézdy Árpád, Major Máté, Perényi Imre. Technikai szerkesztők: Horváth Tiborné, Vámossy Ferenc. I. kötet, 1-2. szám. Akadémiai Kiadó, Budapest 1969. 
1981-ben Gábor László neve fekete keretben jelent meg, majd 1983-ban már ki volt hagyva a neve a szerkesztőbizottságból. 1984-ben Kézdy Árpád neve kapott fekete keretet, 1985-ben már az ő neve is hiányzik. A szerkesztőbizottság ekkor: Kaliszky Sándor, Major Máté, Perényi Imre. 1986-ban Major Máté neve kapott keretet, majd az új szöveg:

Épités- Épitészettudomány. A Magyar Tudományos Akadémia Müszaki Tudományok Osztályának közleményei. Szerkeszti: Szabó János. Szerkesztőbizottság: Kaliszky Sándor, Perényi Imre, Szabó János, Vámossy Ferenc. Technikai szerkesztők: Horváthné Sipos Edith, Vámossy Ferenc. XIX. kötet, 1-2. szám. Akadémiai Kiadó, Budapest 1987-1988.

Újabb változás történt 2000-ben:

Épités- Épitészettudomány. A Magyar Tudományos Akadémia Müszaki Tudományok Osztályának közleményei. Főszerkesztő: Szabó János. Szerkeszti: Vámossy Ferenc. Szerkesztőbizottság: Kaliszky Sándor, Meggyesi Tamás, Szabó János, Vámossy Ferenc. Technikai szerkesztôk: Horváthné Sipos Edith, Gy. Balogh Ágnes XXVIII. kötet, 1-4. szám. Akadémiai Kiadó, Budapest 1999-2000.

Ezt követően jelenik meg a folyóirat 2000. szeptember 15-én kelt, megújulást jelző közleménye, majd az ezt követő szöveg:

Épités- Épitészettudomány. A Magyar Tudományos Akadémia Müszaki Tudományok Osztályának közleményei. Főszerkesztő: Szabó János. Szerkeszti: Vámossy Ferenc. Szerkesztőbizottság: Domokos Gábor, Gáspár Zsolt, Kaliszky Sándor, Meggyesi Tamás, Szabó János, Vámossy Ferenc. Technikai szerkesztők: Horváthné Sipos Edith, Gy. Balogh Ágnes XXIX. kötet, 1-2. szám. Akadémiai Kiadó, Budapest 2001.

A 34. kötet 1-2. számában, 2006-ban, a fenti névsor nem változott. A digitális kultúra korszaka viszont már 2000-ben feltünt. A bibliográfiai szöveg azonban a borító belső oldalán kezdettől megjelent, aminek ekkori szövege rögzíti a lappal foglalkozó tudományterületet: „A folyóirat a Magyar Tudományos Akadémia Műszaki Tudományok Osztályának Elméleti és Alkalmazott Mechanikai, Építészettörténeti és Műemléki, Építészettudományi, Településtudományi Bizottságai által támogatott építés- és építészettudományi tárgyú tanulmányokat publikál." Ez a megfogalmazás tartalmában kezdettől igaz, az egyes bizottságok elnevezése azonban többször változott, az Építészettörténeti és Elméleti Bizottság esetében ugyanúgy, mint a mérnöki tudományok területén.

A társadalom és gazdaság jellemzői ebben az újabb időszakban az államszocializmus még harmad évszázadnyi fennállása idején épp úgy változtak, mint a modernizáció alakuló jegyei vagy a kialakult építőipar és vele az építészet. Az építészetet épp úgy alakította a szocialista országok között irigyelt ,gulyáskommunizmus”, mint a társadalom más jelenségeit. 
Az 1960-as évek második felében az építészetben is érzékelhető megtorpanás vezetett az új mechanizmus kereséséhez. A gazdasági reform nyitó szándékú kezdeményezései a hetvenes évek elején élénkülést és rövid fellendülést eredményeztek. A reform 1974-es elfojtása, az 1973-74-es világgazdasági válság utáni amerikai és európai átrendeződés új eredményeinek lebecsülése, a bezárkózással való újabb próbálkozás ismét gazdasági hanyatláshoz, majd a hosszú pangás állapotához vezetett, ami 1989-ben e diktatórikus világrendszer összeomlását okozta.

1968 és 1974 között a reform természetszerủen megnyitja az építészet számára is a tájékozódás lehetőségét. Az építésiparosításban megjelenik a dán Larsen-Nielsenrendszer is, amelyet azonban a paneles technológia egységesítése során kiszorít a francia eredetü, leegyszerüsített szovjet panelgyártási és tipizálási gyakorlat. A könynyüszerkezetes program mégis megköveteli a nyugati tájékozódást. Nemzetközivé válnak egyes szakmai kapcsolatok, a világszínvonal követése egy ideig cél, amit csak a reform visszafogása feledtet el újra. Többé azonban nem zárható el különféle törekvések - így a hazai organikus építészet vagy az újabb európai tendenciák - érvényesítése elől az út. 1978 után ezért színesebb építészetünk, de rövidesen bekövetkezik a nyolcvanas évekbeli pangás, $\mathrm{s}$ ezzel megindul a tervező vállalatok bomlási folyamata. Korszakhatár természetesen 1989 is.

Miután a folyamatok a kutatás területeit csak közvetve érintik, lapunkban közvetlenül alig érzékelhető a hatásuk, a fontosabb törekvések azonban a cikkekben, szemleanyagokban megjelentek. A folyóirat belső felülvizsgálatát tartalmazó, az MTAnak és az Akadémiai Kiadónak szánt összefoglalásában, A folyóirat 2000. szeptember 15-én kelt, megújulást jelzö közleményében - amit később a 35. kötet Repertórium számában, 2007-ben az 53. oldalon is közöltünk - kimondhattuk:

„Az Épités- Épitészettudomány címü folyóirat 1969 óta a magyar építéstudomány és az építészeti kultúra tudományainak nemzetközi rangú dokumentuma. (...) A tudományos-kutató tevékenység átalakulásának elmúlt évtizedbeli nehézségeit lapunk is átélte. Megváltoztak és leszükültek a szakmai kutatás intézményi keretei, megnövekedtek a laboratóriumokkal ellátott egyetemi kutatás feladatai, létrejött az egyetemi doktori képzés és minősítés új rendje, kialakultak az akkreditált tudományos programok. Mindezzel egyre élénkebbé vált az egyetemi kutatás, egyértelmüvé vált a megújulás és szerepváltás szükségessége."

Ezzel az indoklással jeleztük a lapunk megújítására vonatkozó szándékainkat: „A 2001. évtől ezért a folyóiratot meg kívánjuk újítani, bővítve a szerzői és olvasói kört. A kutatás legfontosabb, rendszeresen megjelenő, gyors átfutási idejü dokumentumaként, de lektorált és szerkesztett jellegét megtartó, továbbra is a legmagasabb szakmai-tudományos igénnyel fellépő szakfolyóiratként kívánjuk lapunkat megújítani, újraszervezve a Szemle és Könyvszemle rovatokat, és lehetővé téve a folyamatban lévő fontos kutatásokra való figyelemfelhívást is. Lehetőséget kívánunk adni az Építőmérnöki és Építészmérnöki Karokon és társintézményeikben tudományos tevékenységet folytató oktatóknak és posztgraduális tanulmányokat folyatató fiatal kutatóknak, illetve $\mathrm{PhD}$-eljárásra jelentkező fiatal tudósoknak arra, hogy a folyóiratban publikálják eredményeiket. Az építéstudomány és a müszaki mechanika 
szakterületei, továbbá az építészettörténeti, elméleti és müemléki kutatások mellett számítunk a tervezésfejlesztés és az urbanisztika tudományos eredményeinek közlésére is.

Szeretnénk területünk szakmai-tudományos szellemi életének kommunikációs feladatait a jövőben maradéktalanul ellátni. Tudományszervezési szándékunk a példányszámban és a terjesztésben is fejlesztést igényel, ezért várjuk felsőoktatási tanszékeink és a köztestületi tagok mellett a tudományos tevékenység iránt érdeklődők vagy azt hasznosítók jelentkezését és előfizetését is. Az egyetemi kutatás fejlesztése és megerősödése olyan feladat területünkön is, amelyben az Európai Unióhoz való csatlakozás éveiben eredményeket kell felmutatnunk. A szerkesztés megújulásával és az előfizetők számának bővülésével, igényeinek jobb kiszolgálásával kívánjuk a megrendült helyzetủ tudományos kutatótevékenység fellendülését előmozdítani."

A 35. kötet Repertórium (1957-2007) számában négyen foglalták össze véleményüket a folyóirat ötven évéröl: Marosi Ernő: Müvészettörténet az Építés Építészettudomány (korábban Építés- és Közlekedéstudományi Közlemények) 50 évének 47 kötetében; Gáspár Zsolt: Az Építés - Építészettudomány 50 évének publikációi a mechanika szemszögéböl; Finta József: Az Építés - Építészettudomány 50 évéhez, avagy épitészetünk ,,szellemtörténete”; Meggyesi Tamás: A szakma színeváltozása az urbanisztikai tárgyú közlemények tükrében.

E négy tanulmány nagyon érzékeny képet összegez a folyóirat fél évszázadáról, és önmagában többet mond jelen írásomnál lapunk múltjáról és a múlt jelentőségéröl, építészeti kultúránkról. Gáspár Zsolt például témaköre 26 akadémikusának 145 tanulmányát említi a száznál több publikáló között.

Fontosságuk miatt ezért e vélemények lényeges megállapításait a későbbiekben összefoglalom, helyenként idézem is, világos képet nyújtva ötven év munkájáról.

\section{AZ ÉÉT MEGJELENT ANYAGAIRÓL ÉS A LAPSZERKESZTÉS PROBLÉMÁIRÓL}

Az 1969-töl 2007-ig terjedő, közel négy évtized belső fejlődését jól jellemzik a jórészt teljes számot kitöltő konferenciatémák és anyaggyüjtések is, amik önmagukban is kirajzolják az építési, müszaki mechanikai, építészeti, építészettörténeti és mủemléki kutatások jellegét. A mintegy tucatnyi fontosabb esemény, személyekhez kapcsolódó köszöntő anyaggyüjtések, kiemelkedő tudósok életpályájának megvilágítása jól jellemzi az ÉÉT témaköreinek változását, a kutatási terület kiszélesedését, fejlődését.

Az V. (1976) kötet 3-4. számában negyven múvészettörténész köszöntötte építészeti témájú tanulmányával Zádor Annát, az építészettörténet tudományegyetemi professzorát. Az iparosított építés építészeti problémáit tárgyaló kétnapos ankét a IX. kötet (1977) 1. számának anyaga. A XII. kötet (1980) 1-4. száma Dercsényi Dezső, a XV. kötet (1983) 1-4. száma Entz Géza, a XVII. kötet (1985) 1-2. száma Rados Jenő köszöntése. Az MTA Müszaki Tudományok Osztálya és a Budapesti Műszaki 
Egyetem által Csonka Pál és Korányi Imre professzorok tiszteletére rendezett, 1986. június 26-i tudományos ülés előadásainak anyaga adott elégtételt a méltatlanul nyugdíjazottaknak: XIX. kötet (1987-1988) 3-4. szám. A XX. kötet (1989) 1-2. száma az MTA Építészettörténeti és Elméleti Bizottságának 1987. október 6-i nyilvános ülése: A hagyománytisztelet erkölcse és értelme címmel. A XXII. kötet (1991) 3-4. száma a Hagyomány és intuíció, A Budapesti Müszaki Egyetem Épitészettörténeti és Elméleti Intézetének 1990. december 13-14-i tudományos ülésszaka. A XXIII. kötet (19921993) 3-4. száma a Feketeházy János születésének 150. évfordulója alkalmából rendezett tudományos emlékülés, 1992. május 12. A XXV. kötet (1995) 1-2. száma Értékrend, hitelesség és eredetiség a müemlékhelyreállitásban. Az 1994. október 26-i OMvH-ICOMOS konferencia elöadásai és vitája. A XXIX. kötet (2001) 1-2. szám Gábor László emlékülés. 2000. november 23. A XXXIII. kötet (2005) 1-2. szám Megemlékezés Major Máté születésének századik évfordulóján. 2004. szeptember 11. Ugyanebben a számban jelent meg Kunszt György tudományos pályafutásának áttekintése és értékelése, a 2004. november 9-i ünnepi ülés nyilvános előadásai. Minden korszak és szándék is kitermeli azonban saját ellentmondásait, ez utóbbi esetben már jóformán az ünnepelt szerkeszti össze életpályája anyagát.

Meg kell még említeni a 38. kötet (2010) 3-4. számában megjelent, 140 éves az épitészettörténet-oktatás a Müegyetemen címü, 2010. április 22-24-i ünnepi ülés elöadásainak anyagát, a 39. kötet (2011) 3-4. számában a Struktúra - textúra - faktúra. Anyagszerüség és digitális technika az épitészetben címü, 2014. május 12-i konferencia anyagát, valamint a 41. kötet (2013) 3-4. számában a Guzsik Tamás emlékkonferencia elöadásainak és a 42. kötet (2014) 3-4. számában a Szentkirályi Zoltán emlékkonferencia 2014. február 6-7-i, az eredeti szándékokhoz méltó elöadásait.

E hosszú korszak áttekintésében a fontos témák sorát sem lehet röviden jellemezni, hiszen csak az ötven évet összefoglaló Repertórium 695 szerzőt említ, és több mint ezer a szerzői művek száma. 316 szerző már az ÉKTK idején müködött, és közülük a különböző konferenciákon 47 külföldi vendég volt a szocialista országokból. Az elmúlt tíz évben 104 új szerző csatlakozott a lap által kiszolgált kutatógárdához, az önálló publikációk száma immár meg is haladja a másfél ezret. A két folyóirat 58 kötetének kutatható témaanyaga az általa lefedett tudományterületen szinte kikerülhetetlenül gazdag.

Ha arra a kérdésre keressük a választ, mire volt képes a folyóirat, hogyan és milyen mértékben töltötte be a hazai tudományos kutatásokban az alapítók által kijelölt és elvárt szerepét, már távolról sem adhatunk ilyen magabiztos választ. Egyáltalán milyen mértékben valósult meg mindaz, amit a társadalmi váltást követően a megújulás lehetőségével 2000-ben célul tüztünk, megfogalmaztunk és az előzőekben idéztünk? Mit tettünk az elmúlt 17 évben szaktémáink áttekintésében, fejlesztésében, a témakörök felfuttatásában, elmélyítésében saját felelősségünk területén? Hogyan segítet- 
tük a doktori képzést, egyes fontos témák napirendre tüzését, egyáltalán sikerült-e területünk szakmai-tudományos szellemi életének feladatait kellő mértékben, ha nem is maradéktalanul, ellátni?

Tudományszervező szándékunk ellenére a kinyomtatott példányszám lecsökkent, a terjesztés a számítógépes közléssel szemben háttérbe került, ugyanakkor az is kétségtelen, hogy a tudományos kutatásban az anyagokat hosszú időre kell megtartani és hozzáférhetővé tenni.

A digitális kultúra új, sokat ígérő megjelenésével a kiadó lapunkat digitális formában tette elérhetővé, mert az ebben a formában új virtuális lehetőségeket jelentett számára. Itt hosszabban kell érvelnünk. A szemléleti tévedés az alapja ugyanis annak a sokak által örömmel fogadott felfogásnak, hogy a 3D-s ábrázolás a virtualitás képességével minden feladatot, így a tudás birtokában a hosszú időn át való fenntartás lehetőségét is biztosítja a papírra nyomtatott tudásanyag ismert tulajdonságaival szemben. A gépi kultúra virtuális lehetőségeinek birtokában elhomályosult a tudásanyag hosszú időre történő megörzésének szándéka. Saját tapasztalatomból tudom, hogy a csak digitális alapon történő, egy központú megörzés az egyszer már megszerzett tudás elvesztésével járhat. Egy sok munkával összeállított, Az épitészeti kultúra Magyarországon címü, tízíves írásom, amelyet a METESZ kérésére készítettem, s amelyet a METESZ tíz másik témával együtt fontos tájékoztató anyagként Magyar Technikatörténeti Kalauzként 1998-ban a világhálóra tett, tizenkét évvel később egyszerüen lekerült a hálóról és a semmibe merült, mondanivalója pedig most is aktuális.

A virtualitás tehát nem túlértékelhető, igaz az Idegen szavak és kifejezések szótára (Akadémiai Kiadó, Budapest 1994) értelmezése. Eszerint: „virtuális lat 1. látszólagos, elképzelt, nem valódi 2. lehetőségként létező, benne rejlő 3. fiz látszólagos, ernyőn fel nem fogható (kép)". Mint ahogyan a 3D-s ábrázolás sem maga a tényleges fizikai valóság.

Lapunk anyaga is hosszú időre érvényes kell, hogy legyen. Ez vezette a szerkesztőséget arra, hogy a Repertórium számot elkészítsük, ahol a tartalomjegyzékek kivonata és a szerzőnevek mutatója a gyors kereséshez állandó biztos alapot ad. E számunkat követően 2008-ban a Magyar Tudományos Akadémia és az Akadémiai Kiadó Nívódíjjal ismerte el lapunk tudományos teljesítményét.

A digitális világhoz természetesen alkalmazkodnunk kell, de kinyomtatott példányokban is fenn kell tartani a terjesztést. Más vonatkozásban, úgy hiszem, elképzeléseinket teljesítettük, egyetlen megfelelő minőségü kéziratot sem utasítottunk viszsza, lehetőséget adtunk a viszonylag gyors megjelenésre mindenkinek, ezzel is segítve a doktori képzés követelményeinek teljesítését. Úgy a mérnöki, mint az építészmérnöki képzésben a témavezetők és doktoranduszjelöltek együttműködését segítjük. Ezen a téren a szerkesztőbizottság igen komoly segítséget nyújt, és a szerkesztőség egészében jó az együttmüködés. Ugyan e téren megítélésem szerint az elmúlt másfél évtizedben is jó szinten teljesítettük a vállalt feladatot, együtt vállalva a felelősséget.

Nem akarom azt állítani, hogy a szerkesztői munkában soha nem volt félreértés, vita, ellentmondás vagy értetlenkedés, vagy az elfáradás okozta csüggedés, elbizony- 
talanodás, nagy ritkán belső feszültség vagy a munkát hátráltató más probléma, de meggyőződéssel állítom, hogy az esetlegesen előforduló ellentéteket elsimította az együttmüködés igénye, a jó szándékú megegyezés.

Fontos kérdés a szerkesztésben a témák támogatásának kiválasztása, s ezzel kapcsolatban az egyes szerzők támogatása a témák feldolgozásában. A folyóirat jellegéből következik, s ez a doktori követelményekkel is egybevág, hogy a téma kidolgozása akadémiai igényszinten történjék meg. Ez fontos feladatot jelent a témavezető, a lektor és a szerkesztő számára is.

A követelményeket megszabja azonban a folyóirat jelleg is, az önálló publikálásra alkalmas, folyóiratba illő terjedelem. A könyv igényü témák feldarabolása vagy a közönséges szakfolyóiratba illő kifejtés itt egyaránt hibás megoldás, túl nagy terjedelmü cikket vagy gyenge minőségủ illusztrálást éppúgy nem fogadtunk el, mint nem akadémiai lapba illő szövegkifejtést. Ezek a követelmények csak az érintettek közös figyelmével tarthatók meg.

\section{AZ ÖTVEN ÉV ÉRTÉKELÉSÉNEK FONTOSABB MEGÁLLAPÍTÁSAI}

Ezek után térjünk vissza a Repertórium számban áttekintést vállaló négy szerző megállapításaihoz.

Marosi Ernő mint külső bíráló megállapította, hogy az ötvenedik év gyakori a tudományos folyóiratok esetében, és e nagy idő három tudományos generációnak felel meg, s így a szakmai emlékezet, a tudománytörténet forrása is. Felveti, hogy megoldatlan a közelmúlt digitális publikációinak elérése, mivel a folyóiratoknak archiváló szerepük is van. A folyóirat - még az ÉKTK tágabb területet átfogó füzeteiben is - egészében fontos művészettörténeti forrás, közleményei a kor építészetének technikai és elméleti hátterére világítanak rá, s az óbudai Árpád-hidat és a hézagmentes vasúti pályát említi példaként. Kiemeli Pogány Frigyes és Granasztói Pál várostörténeti és urbanisztikai írását fontos kezdetként, majd rámutat a kor technikai eredményeit bemutató közlemények jelentőségére, a bauxitbetontól és ponyvasátortól A hagyománytisztelet erkölcse és értéke címü konferenciáig terjedő szellemi és ízlésbeli látókör korfestő szélesedésére.

A két folyóirat az idő nagy részében a müvészettörténeti publikációk fontos fóruma volt, $\mathrm{s}$ az építészetet képzőmủvészetnek tekintő álláspontot elemzi, jelezve, hogy a mủemlékvédelem a mủvészettörténetnek is egyik legfontosabb forrása. Évszázados hagyománynak tekinti Steindl Imre óta a Műegyetem Építészettörténeti Tanszékének kutató szerepét, müemlékfelméréseit, Lux Kálmán és Géza, Csányi Károly és Csemegi József nevét említi, az új generációból Czagány István, Cs. Tompos Erzsébet, Major Jenő, Guzsik Tamás, Sódor Alajos munkásságát, a müemlékesek közül Gerő László, Borsos Béla, Komárik Dénes, Bibó István nevét. Az építészet elméleti kérdéseivel való foglalkozásban Hajnóczi Gyula, Szentkirályi Zoltán, B. Szücs Margit, Hajnóczi Gábor neve merül fel. 
Az 1960-as évektől kezdve az MTA Építészettörténeti és Elméleti Bizottsága foglalkozott a magyar építészettörténet nagy kézikönyvének előkészítésével, ezt a témát az Építészettörténeti Albizottság irányította (Vargha László: Magyarország építészettörténete, ÉÉT II. 1970. E feladatot később az MTA Művészettörténeti Kutatóintézete vette át.) A témakör a nagy konferenciákban rajzolódik ki.

Az első Épitészettörténeti és müemlékvédelmi konferencia jelentős, nemzetközi részvéttel vitatott müvészettörténeti referátumát Gerevich László tartotta Középeurópai királyi mühelyek a XIV. században és a későgótika címmel (ÉKTK II. 1958). A II. konferencián hasonlóan fontos Zádor Anna A magyarországi klasszicizmus európai elözményei és Csemegi József Közép-Európa román kori centrális templomainak épitészettörténeti kérdései címü előadása (ÉKTK IV. 1960). A III. konferencián ugyanilyen fontosságú volt Dercsényi Dezső referátuma Közép-európai épitészettörténet felé címmel (ÉKTK VIII. 1964).

Müemlékvédelmi szemléleti és metodikai kérdéseket tárgyalt az 1964-es Nemzetközi müemlékvédelmi munkaértekezlet (ÉKTK X. 1966). Ezeknek a publikációknak Marosi szerint szemléletet formáló, iskolateremtő érdemük volt. Alkalmat adtak ilyen publikációkra a müvészettörténészeknek ajánlott tanulmánykötetek is. Marosi megemlíti, hogy a müemlékvédelemmel foglalkozó közlemények tematikája az 1970-1980-as években megváltozik, konzerválás- és vegyipari közlemények váltják a műemléki témákat. Említi az új témákat: Bauhaus-szám (ÉÉT IX. 1977), magyar formatörekvések (ÉÉT XI. 1979), a nemzeti építészet körüli viták (ÉÉT XX. 1989, XXIV. 1994), Molnár Farkas (ÉÉT XX. 1998). Külön felsorolásban említi a közös gondolkodást megújító témákat: A hagyománytisztelet erkölcse és értelme (ÉÉT XX. 1989), Hagyomány és intuíció (ÉÉT XXII. 1991), Értékrend, hitelesség és eredetiség a müemlék-helyreállitásban (ÉÉT XXV. 1995), Inspiráció (ÉÉT XXIX. 2001), Alkotás és müalkotás az épitett környezet világában (ÉÉT XXVIII. 1999-2000).

Gáspár Zsolt elemzése bevezetőjében megállapítja, hogy az Épités - Épitészettudomány és jogelődje jelentős helyet foglal el a hazai építő-, építészmérnöki tudományok publikációinak sorában. Ennek jellemzésére emeli ki azt a tényt, hogy az elmúlt 50 év alatt 26 akadémikus (vagy aki később lett akadémikus) publikált a lapban. Az alábbi neveket említi: Bogárdi János, Bölcskei Elemér, Csanádi György, Csonka Pál, Domokos Gábor, Finta József, Gáspár Zsolt, Gerevich László, Hajnóczi Gyula, Halász Ottó, Haszpra Ottó, Kaliszky Sándor, Kézdi Árpád, Kollár László, Kollár Lajos, Kovács György, Kurutzné Kovács Márta, Marosi Ernő, Mihailich Győző, Michelberger Pál, Mosonyi Emil, Páczelt István, Palotás László, Szabó János, Széchy Károly és Tarnai Tibor.

Áttekintésében a továbbiakban csak a szilárd testek mechanikájával foglalkozó cikkeket ismerteti. Az ÉKTK-ban az első évben többen vasbetongerendák számításával foglalkoztak, a második évben (1958) Csonka Pál már előregyártott szerkezeti elemek stabilitásvizsgálatával foglalkozott.

„1959-től kezdve sorra jelennek meg a héjak és héjívek statikai és stabilitásvizsgálatáról szóló cikkek, amelyek később több nagysikerü könyvbe is bekerülnek (Kollár, 1973; Kollár és Dulácska, 1975; Csonka, 1987). 
Az egyenestengelyü, prizmatikus rúd elemzése is nehéz, ha csavarják (Palotás László, 1959), vagy különlegesek a peremfeltételek (Lipták László, 1960), vagy feszítve van (Goschy Béla, Balázs György, 1961). Kaliszky Sándor (1961) a beton és vasbeton tárcsák, Andor Béla és Iványi György (1963) hajlított vasbetonszerkezetek teherbírásának számításához ad képleteket.

Korábban analitikus módszerrel keresték a mechanikai problémák megoldását, de 1965-től megjelenik a mátrixszámítás, a numerikus módszereket ismertető cikkek. Béres Elek (1965) a tartórácsok elemzését, Szabó János (1965) pedig a kötélhálók állapotjellemzőinek nemlineáris egyenletrendszerekkel való meghatározását mutatja be. Roller Béla (1966) is a kötéltetőt vizsgálja, de differenciálegyenleteket használ.

Szalai János (1965) a Fourier-sornak ad statikai értelmezést. Cholnoky Tibor (1967) a Mohr-féle tenzorábrázolást fejleszti tovább. Németh Ferenc (1968) a ferde vasalású vasbeton lemezek méretezésére szolgáló összefüggéseket vezeti le. Vértes György (1968) jelenteti meg az első dinamikai tárgyú cikket a magasházak önrezgésének számításáról."

Az Épités - Épitészettudomány (1969-2006) összefoglalását nem lehet rövidebben összegezni, mint az a nyolc oldal, amit a Repertórium kötetben elfoglal Gáspár Zsolt tanulmánya. E helyen erre nem vállalkozhatok.

„Megállapíthatjuk - írja Gáspár Zsolt -, hogy ez az 50 éves folyóirat a szilárd testek mechanikájának magyar nyelvủ irodalmában nagyon jelentős helyet foglalt el. Különböző vasbeton, acél-, fa- és ponyvaszerkezetek tervezésénél fellépő statikai, dinamikai és stabilitási problémák megoldására adtak megoldásokat, valamint érdekes elméleti kérdéseket is elemeztek. Sok szerző itt közölte a készülő disszertációja egy-egy fontos tézisét, megjelentek akadémiai székfoglalók áttekintő előadásai. Több helyen utaltunk arra, hogy az itt megjelent cikkek bekerültek a szerzők későbbi nagy sikerü könyveibe. Ennek a megállapításnak a megerősítésére megadjuk, hogy Kollár L. [1991] szerkesztésében megjelent sokszerzős stabilitási problémákkal foglalkozó könyv (mely azóta külföldön is megjelent) az ünnepelt folyóirat következő 17 cikkére is hivatkozik: Bódi István (1986), Dulácska Endre (1963), Dulácska Endre és Kovács Imre (1971), Gáspár Zsolt (1977, 1984), Halász Ottó és Iványi Miklós (1978), Kollár Lajos (1960, 1961, 1962, 1963, 1984), Kollár Lajos és Bódi István (1984), Lipták László (1960), Popper György (1978), Tarnai Tibor (1979, 1984), Zalka Károly (1982)."

Gáspár áttekintéséből kitünik, hogy a két lap fennállásának idején az egyszerü analitikus és numerikus számításoktól a számítógépek fejlődésével, új módszerek megjelenésével a nemlineáris anyagi és/vagy fizikai módszerektől a tudomány minden területén a katasztrófaelmélet felhasználásától, a szerkezetek képlékeny méretezési eljárásától, a héj- és rúdszerkezetek stabilitásától a ponyvaszerkezetek területéig vagy a biomechanikáig, nemlineáris eljárásokkal a vasbetonszerkezetekben a húzott beton merevítő hatásának figyelembevételéig és számtalan más új felismerésig a hazai mechanika területén a lapunkban közölt tanulmányaikkal eljutottak.

Finta József kiindulásként említi, hogy szakmai életútja egyidős a folyóirattal, és az 1960-as, 1970-es évek korszakát sem értékeltük-elemeztük még végérvényes 
igazsággal. Az időszak építészete, építőiparának eredményessége, építéstechnikai, technológiai és szervezési modernizációja, szaktudományi intézményrendszerének fejlődése és működése s egyúttal a nemzetközi építészeti szervezetben játszott szerepe nem kérdőjelezhető meg akkor sem, ha ezeket a kérdőjeleket a mai építészeti kritika nagyon kegyetlenül rajzolja fel.

E hazai modernizációs folyamatok, illetve a mögöttük álló szaktudományi kutatás fejlődése, a szervezőmunka és konferenciarendszer, a hazai tudományos közélet és tevékenység egészének alakulása, értékeivel és ellentmondásaival együtt tükröződik a lap ötven évet átfogó publikációs jegyzékeiben. Felrajzolható belölük építészetünk egészének ,szellemtörténete” is. Finta sajnálja, hogy egyes folyóirataink tendenciózusan írják le az előző évtizedek generációinak munkáját, nem jutva el a kor komplex elemzéséig.

Építészetünk és építőiparunk, mérnöki cselekedeteink hatalmas erőfeszítésének az eredménye volt, hogy szegénységünk, elzártságunk, politikai-gazdasági kalodánk minden nyomorúsága ellenére legalább szellemében ne maradjunk le az európai építészet mozgásától. Ezeket az erőfeszítéseket csak az érti meg, aki tudományos szerénységgel és morális értelemben is fundamentált ambícióval, az igazságkeresés elszántságával kíván közelíteni ezekhez az évtizedekhez.

Az Épités - Épitészettudomány, illetve elődje, híven elveihez, szerkesztöi alapeszményeihez, majd mindenkor ezzel az akarattal-céllal fordult a benne publikált témákhoz, problémákhoz. Nem tagadható, hogy (főként a hatvanas években) írásainak egy része a korabeli építés- és kultúrpolitika által „ihletett” módon, kvázi politikusan közelített témáihoz, de az sem feledhető, hogy épp ez volt az egyik hely, ahol a magyar építészetet törekvéseiben megpróbálták belehelyezni a nagy nemzetközi mozgásokba. Példaként a kor nagy világmozgalmait említi, a klasszikus moderntől az újbrutalizmuson, strukturalizmuson, a metabolista irányzatokon vagy a posztmodernen, az induló high-techen át egészen az azokhoz kapcsolódó organikus mozgalom antropomorf-biomorf vagy regionalista, minimalista „hitekig”. A magyar építészet, minden negatív, öt satuban tartó mozgástere ellenére (megosztott társadalom, konfrontatív politika, romló gazdaság, vizuális alulmaradottság stb.) nem tért ki a felsorolt irányzatok kihívásai elöl.

Finta külön említi a magyar müemlékvédelmet európai szintre emelő nagy generációt, Gerő László, Rados Jenő, Dercsényi Dezső, Entz Géza, Horler Miklós, Pogány Frigyes nevét, és a hazai előgyártó ipar, a szilárdságtani problémák, az építési technológiák, anyag- és minőségi vizsgálatok tárgykörében magas tudományos szinten prezentáló és elemző szerzők témáit.

Az Épités-Épitészettudomány eddigi, fél évszázados „élete” során mindenkor a legszigorúbb elvi-tudományos (és szakmai értelemben is etikai) alapokon állt, eszerint válogatta, közölte írásait. Tette ezt olyan közegben, amikor ez a szakmai moralitás igencsak „olvadóban” van. Finta károsnak látta, hogy a lap nem juthatott izgalmasabb, piacképesebb formához, s így nem vállalhatja fel a külhoni propaganda missziójának szerepét. Ebben a helyzetben a lap nem tehet mást, mint hogy járja továbbra is a maga útját. Ezért volt fontos a folyóirat müködése, amely az urbanisz- 
tikának és településtudománynak, illetve az építészetelmélet-kritikának és az építészeti tervezés módszertani fejlesztésének, a tervezéselméletnek témáit állította a múltban is előtérbe az építészettudomány szempontjából. Az építészetnek, azon túl, hogy végre meg kellene találnia társadalmi párbeszédhátterét, egyre jobban kellene támaszkodnia a hazai és nemzetközi szaktudomány kutatásaira (konstrukciós, anyaghasználati, energetikai és szociális-társadalmi értelemben egyaránt).

Ezt az elvet felvállalva, ezt tudatosítva lehet akadémiai folyóiratunk egyre fontosabb forrás korunkban. Az építészet furcsa létezése a müvészetek és tudomány között, vagy épp az Akadémián belüli nem szervesülö helyzete és labilis pozíciója a politikában, az országirányítás adminisztrációjában egyenesen megköveteli, hogy legyen olyan hiteles fóruma, hiteles szószólója igazságainak, amely fórum értékítéletei, kinyilatkozásai megkérdőjelezhetetlenek.

Meggyesi Tamás áttekintését ezzel a megállapítással kezdi: „Ötven év, vagyis egy fél évszázad egy szakma fejlődéstörténetében - különösen a felgyorsult idő jegyében - egyrészt nagyon rövid, másrészt túlságosan is hosszú. Rövid, mert egyetlen emberöltőt fog át, de hosszú, mert ez idő alatt drámai történelmi és társadalmi átalakulásokat értünk meg, aminek hatására a legtöbb tudomány lényeges szemléleti átalakuláson ment át. Különösen igaz ez az urbanisztikára, aminek tematikája mindig is ki volt szolgáltatva az adott időszakot meghatározó urbanizációs tendenciáknak. Ez alatt az ötven év alatt a nagyvárosok a maguk abszolút, majd relatív centralizációjától kezdve átmentek a relatív centralizáció, ill. a szuburbanizáció és a dezurbanizáció és a re-urbanizáció egymást átlapoló fejlődési szakaszain. Eközben drámai módon változtak a városépítési feladatok és ennek tükrében változott a szakma identitástudata is."

Meggyesi összehasonlítja Nyugat-Európa „municipális szocializmusát” a keleti blokk államszocializmusával, a ,jóléti állam” kialakulását említi és a létező szocializmus összeomlását, a „Településtudomány” néha fontoskodó tanulmányait a nyugati, alkalmazott rendszerelméleten és szervezéstudományon alapuló technokratikus szemlélettel, említve a párizsi diáklázadások keltette kiábrándulást. Közben a tudományelméleti meghatározások iránti vonzalom csak lassan hagyott alább, miközben a Nyugat végleg eltávolodott nemcsak az ideológiáktól, hanem a tévedhetetlen tudományos elöítéletektől is.

Az elmúlt 50 évben az urbanisztika és településtudomány, illetve településtervezés egyik vonulata ideológia- és politikai kurzusfüggő volt. A „dogmatikus” hangvételü közlemények 1956 után is hirdetik a szocializmus megváltó távlatait. Ide tartoznak Perényi Imre és Faragó Kálmán, Gerle György és Novák Péter tanulmányai. Idesorolja Perczel Károly és Kőszegfalvy György munkásságát is, amely azonban a jobb hagyományt, Teleki Pál, Kiss István és Mendöl Tibor munkásságát követi.

Tudományelméleti közléseket tárgyal a szerzők második csoportja, így Brenner János, de különösen Granasztói Pál, akinek Épitészet és urbanisztika címü összegző írásai értékes anyaggal járultak hozzá a tudományelméleti kérdések tisztázásához. Valló István és Harrer Ferenc a társadalomtudományok felé orientálódtak, míg Vidor Ferenc „holisztikus” megközelítése inkább interdiszciplináris, az angolszász „szak- 
mai mássághoz" közelít. A harmadik csoportot alkotók a településtervezés normativitásával foglalkoztak, a logikai-matematikai eszköztár vagy a rendszerelmélet alapján. Brenner János, Zsitva Tibor, Jándy Géza és Bakai Jolán mellett a maga korai tevékenységét is idesorolja a szerző.

A negyedik csoportba sorolhatók a történettudomány mủvelői, akik településtörténeti vagy építészettörténeti, müemléki és városképvédelmi munkásságukkal kapcsolódnak. Mindenekelőtt Korompay György, Granasztói Pál írásai, Major Jenő, Preisich Gábor Budapest történetével foglalkozó írásai és Perényi Imre $A$ városépités története című müve tartozik ide. Pogány Frigyes, Hajnóczi Gyula, Szentkirályi Zoltán, Román András egyes írásai és a Városképek - Müemlékek sorozat is ide kapcsolhatók.

A rendszerváltásig még az Építészettörténeti és Elméleti és a Településtudományi Bizottság is rendezett együtt konferenciákat. A lap Szemle rovatában Percy Johnson Marshal, Lewis Mumford és Thomas Sharp könyveiről is jelentek meg ismertetések.

Egyes közlemények az urbanisztika határterületeire tartoznak, ilyenek a településföldrajzi tárgyú, a város mérnöki létesítményeivel és a közüzemek müködésével foglalkozó tanulmányok és egyes zöldterületi tervezésről szóló írások.

Hiányként állapítja meg Meggyessy az önkormányzatisággal és ingatlanfejlesztéssel, valamint e kettő kapcsolatával foglalkozó területet. Megjegyzi azt is, hogy az „építés”, „építészettudomány” név felvétele az urbanisztikában csak lassan vált az identitástudat részévé, és generációs problémává alakult. Az „idősek” (a településrendezők) nehezen mondtak le a térszerkezet kétdimenziós irányításának elsőbbségéröl, a ,fiatalok" (az építészek) pedig már nem hittek a szabályok mindenhatóságában. A Településtudományi Bizottság, amelyik régente még egy-egy teljes számot meg tudott tölteni közleményeivel $(1965,1976)$, mára elhallgatott. Egyébként is inkább a regionális és földrajztudományokkal keresi a szövetséget.

A folyóirat elmúlt 50 évének számai nemcsak a szakterület(ek) tematikájának átalakulásáról szólnak, hanem a kutatásokról, a tudományos vitákról, a kandidátusi és akadémiai doktori értekezésekről és az új szakkönyvekről is beszámolnak. Ezzel fontos, és a továbbiakban is nélkülözhetetlen, fórumot biztosít, ahol egy meglehetősen széles spektrummal rendelkező tudomány müvelöi átélhetik összetartozásukat és identitásukat. Különösen fontos ez az urbanisztika területén, aminek mára nemcsak kontúrjai és kapcsolódásai homályosultak el, hanem identitása is elbizonytalanodott. Egy ilyen több magvú, többszörös identitású szakterület esetében különösen fontos, hogy éljen az MTA által felkínált lehetőséggel, és hogy ennek a kiadványnak a segítségével is keresse szövetségeseit.

\section{A SZEMÉLYES FELELŐSSÉGRÖL}

Az elmúlt ötven évet mérlegelő négy tanulmányt talán nem felelötlenül idéztem akkor sem, ha tudom, hogy két szerző, Gáspár Zsolt és Meggyesi Tamás egyúttal mint a szerkesztőbizottság tagja eleve elfogult volt, hiszen maga is hozzátartozott a 
Szerkesztőséghez és benne dolgozva, a felelősség egy része eleve rájuk is hárul. Nem tudok azonban az 50 évben egyetlen nyílt támadásról vagy akár suttogó bírálatról, amit a lapról értékelö ítéletében negatívnak tekinthettem volna. Hangsúlyoztam már, hogy a Szerkesztőség minden tagját a közösség részének tekintve, a lapot közösen szerkesztett munka eredményének tartom, és így nyugodt szívvel fogadom el az általam is idézett elismerô megállapításokat.

Más a helyzet az elmúlt tíz évben, ahol addigi szerepemet végig betöltöttem, $\mathrm{s}$ ahol most az elmúlt évben igen komoly kritika érte lapunkat épp a legfontosabb illetékes részéről, a Scopus értékelő bizottsága kritikájaként. Miután négy évvel ezelőtt jeleztem visszavonulási szándékomat, és az Akadémiától szerkesztőhelyettes kijelölését kértem, lehet, hogy talán túlzottan is visszavonultam az aktív munkától. Lehet, hogy közöltünk túl hosszú és kevés újdonságot tartalmazó cikkeket - a 2013-2015. évek lapszámait bírálták meg. Egészében nem értettem egyet a kapott bírálattal, az azt megtárgyaló szerkesztőbizottsági ülésen azonban a reám eső felelősséget vállaltam. Jelenleg azt vizsgáljuk, milyen módon tudjuk kiküszöbölni az észrevételezett számoknál megállapított hibákat, hiányosságokat. Ezeken kívül felmerült többek között a lap címének angol nyelvü kiegészítése és az angol nyelvü cikkek nyelvi helyességének kontrollálása, szerkesztőbizottsági változások végrehajtása, bővítése, a lap céljának, szakterületeinek újragondolása, az elektronikus kezelés következetes végrehajtása, elektronikus kézirat-bonyolító rendszer használata. Mindez a Szerkesztőség személyi változásaival is összefügg, ezért utódaimra vár az átgondolás és az elhatározottaknak közös felelösséggel történő végrehajtása.

Saját személyes felelősségemet a következőkben érzékelem: Életem nagy élménye és lehetösége volt, hogy kezdettöl fogva, 1958-tól jelen voltam a szerkesztés munkájában, a Szerkesztőség müködésében, s így végig velem is kapcsolódtak a Szerkesztőbizottság tagjai, a technikai szerkesztésben együttmüködők és természetesen a lap szerzői és lektorai. Felelősségemet ezért végig érzékelem a szerkesztőktől, főszerkesztőktől függő változó feladataimnak megfelelően. Minden igyekezetem az összhangban történő együttmüködésre irányult. Nehéz korszakokat éltem át egyes vezetőim, így Szabó János főszerkesztőm hosszú betegsége alatt, amikor a sajátomnál több feladatot kellett ellátnom. E téren most talán hibát is követtem el, amikor - az Akadémia engedélyével - lehet, hogy túlzottan is visszavonultam a mindennapi munkától.

Pályámat végiggondolva, elsőként ki kell mondanom, úgy emlékszem, nem fogadtam el kierőszakolt írásokat közlésre, és magam sem óhajtottam egyeseket előnyben részesíteni vagy éppen félretolni. Úgy hittem, az alapos tájékozódás és figyelemmel kísérés meg kell, hogy előzze a szerkesztői munkát, mivel a lap színvonalának egyenletesen magasnak kell lennie, az akadémiai kutatás színvonalát kell tükröznie, s ezért minden káros nyomásgyakorlást ki kell védeni. Ezt tartottam a szerkesztői tevékenység legfontosabb jellemzőjének, amiben igen fájdalmas, ha úgy érezzük, hogy hibát követtünk el, vagy hagytunk más által elkövetni.

Úgy gondolom, helyes volt, hogy egyaránt fontosnak tartottam mind a két egyetemi kar tevékenységének gondos kiszolgálását, mindkettő szemléletének képvisele- 
tét és érvényesítését, és a közleményekkel alakítását. Pályám során érzékelnem kellett mindkét tudományos területen azoknak belső fejlődését, változásait, a fő témakörök figyelemmel kísérésének, a szerkesztésben való alkalmazásának kötelezettségét, s a közlések jelentőségének fontosságát. Mindez együtt kell, hogy irányítsa a szerkesztő munkáját, a lektor megválasztásától az illusztrációs anyag leggondosabb válogatásáig. De egyúttal ebben van e munka örömforrása is, amiért érdemes volt egész életem folyamán vállalni azt a feladatot, amit e folyóirat 60 éven át számomra jelentett. Munkaidőm mintegy hatodát töltöttem a lappal.

Sorsomnak hála, hogy a költő szavaival - e munkában sokunkkal együtt - kimondhatom:

„Köszönjük élet! áldomásidat, Ez jó mulatság, férfi munka volt!"

(Vörösmarty Mihály: Gondolatok a könyvtárban) 


\title{
6O YEARS OF THE JOURNAL ÉPÍTÉS - ÉPÍTÉSZETTUDOMÁNY (ARCHITECTONICS AND ARCHITECTURE)
}

\author{
FERENC VÁMOSSY \\ Doctor of the Academy, professor emeritus, editor of Épités - Épitészettudomány. \\ Department of History of Architecture and of Monuments, BUTE. K II 82, Müegyetem rkp. 3, \\ H-1111 Budapest, Hungary. Phone: +36-1-316-3877
}

In his retrospection the author - as a member of the editorial team of the journal Épités Épitészettudomány (Architectonics and Architecture, abbreviated ÉÉT), formerly Épités- és Közlekedéstudományi Közlemények (Publications in Building and Transport Sciences, abbreviated ÉKTK) - from 1957, aims to illustrate the journal's history, tasks and their completion. This journal served the scientific and intellectual aspects of the Faculty of Engineering and Architecture at the Budapest University of Technology and Economics. He aims to fully demonstrate not only the journal's internal development over the years but also the entirety of the contemporary scientific research of the time. This was supported by a study published in three languages (Hungarian, English and German) in 2007 written by four experts. It was a comprehensive, evaluative piece that analysed the main scope of work, and included a summarising table of contents.

The era of the EKTK (1957-1968) covers an even wider field which is the developmental period of the scientific fields of academic research. From 1969, in the period of the ÉÉT, the common field of theoretical and applied mechanics and the building sciences made up the engineering specialisation, while the other consisted of architecture, history of architecture, monuments and urban studies. The year 2000 was a special year in the journal's life with the start of the digital age. The effects of internal changes within the university, like the introduction of the doctoral schools amongst other institutional changes, could already be felt in the 1990s.

In his article, the author summarises the most important findings written by the four experts. Ernő Marosi, art historian, analysed the connections between architectural history, monuments and theory of architecture. His study was also an appreciation of the journal's significance in the history of art. Zsolt Gáspár, member of the editorial board, analysed the inner developments of mechanical sciences and its continuing progress, taking into consideration all authors working in this field and studies made in the past 50 years. József Finta examined the journal from a creator-designer point of view and looked at its role in the development of architectural design approach in Hungary. Tamás Meggyesi viewed and commented on the published studies from an urban studies and town planning point of view. Finally, the author is talking about his roles and responsibilities in the life of the editorship. He regards his most important achievements being the formation of the editorial team and the tangible cooperation within the editorial activities, considering that his retirement will bring his 60 year long service to an end.

Keywords: editorship, scientific and intellectual life, scientific field, cooperation 


\section{ERA OF THE BUILDING AND TRANSPORT SCIENCES. 1957-1968}

The first issue of the journal founded by the Section of Engineering Sciences of Hungarian Academy of Sciences in 1957 was published with the following bibliographical data:

Épités- és Közlekedéstudományi Közlemények (Publications in Building and Transport Sciences). Bulletin of the committees on Building Science, on History and Theory of Architecture, on Building Material Science, on Hydrology and Water Management, on Transport Engineering and on Urban Studies of the Section of Engineering Sciences of the Hungarian Academy of Sciences. Editor-in-Chief: Győző Mihailich. Editor: Máté Major. Editorial board: Béla Czére, László Gábor, Pál Granasztói, Tibor Gyengő, Jenő Király, Woldemár Lászlóffy, Máté Major, Frigyes Pogány, Antal Reischl. Vol. I. No. 1-2. Budapest 1957.

Bibliographical data changed in 1960: Épités- és Közlekedéstudományi Közlemények (Publications in Building and Transport Sciences). Bulletin of the committees on Building Science, on History and Theory of Architecture, on Hydrology and Water Management, on Transport Engineering and on Urban Studies of the Section of Engineering Sciences of the Hungarian Academy of Sciences. Editor-in-Chief: Győző Mihailich. Editor: Máté Major. Editorial board: János Bonta, Béla Czére, László Gábor, Pál Granasztói, Woldemár Lászlóffy, Máté Major, Frigyes Pogány, János Szabó. Technical editor: Ferenc Vámossy. Vol. IV. No. 1-2. Budapest 1960.

Even though changes took place before 1965, like the passing of Győző Mihailich and the leaving of other members of the editorial board, the text only changed then: Épités- és Közlekedéstudományi Közlemények (Publications in Building and Transport Sciences). Bulletin of the committees on Building Science, on History and Theory of Architecture, on Hydrology and Water Management, on Transport Engineering and on Urban Studies of the Section of Engineering Sciences of the Hungarian Academy of Sciences. Editor-in-Chief: Máté Major. Editorial board: János Bonta, Béla Czére, László Gábor, Pál Granasztói, Woldemár Lászlóffy, Máté Major, Frigyes Pogány, János Szabó. Technical editors: Tiborné Horváth, Ferenc Vámossy. Vol. IX. No. 1. Budapest 1965.

After completing a five-year designer placement I joined the editorial team, in Máté Major's Department in 1957 who requested my help in compiling the first issue of the journal. My ambition was to support the contemporary scientific life of both the Faculty of Civil Engineering and Faculty of Architecture at the Budapest University of Technology and Economics and to direct the members of the editorial board which represents them. To achieve this a lot of briefing and support was given in the case of topics unfamiliar to me. I took detailed minutes at editorial board meetings. My role model was my former professor, Pál Csonka, who took on the responsibly for Acta Technica, the faculty's English journal, at the age of 70. For me this was a time of learning and adapting. I felt that I received enough guidance for this from my abilities, basic training, former teachers and members of the editorial board. This era was characterised by the efficient work of the editorial board. From 
1965, Mrs Edith Horváth Sipos and myself together edited 12 volumes of the Épitésés Közlekedéstudományi Közlemények (ÉKTK) (Publications in Building and Transport Sciences). Following the Academy and science institutions' reformation at the beginning of 1950, this era was described as the post 1957 development from a scientific point of view, and a time of development and modernisation for new technical and technological processes and organisational methods from an engineering prospective.

The aim of the state socialism forced upon Hungary was to establish the foundation for the socialist and communist society through the society's complete transformation. This forcefully accelerated modernisation was the tool regarded most useful in achieving this objective. The plans were supported by arrangements like the centralisation of institutions supporting the community and economy, scrutiny of their financial and intellectual processes, regulation of community life and all aspect of production to the last detail, ideological pressure that rejects any other way of thinking and the coercive measures of planned economy.

Following the fulfilment of this planned economy's coercive measures introduced in Hungary during this period of chaos and reprisal after 1956, a new era started at the beginning of the sixties with social consolidation and the renewal of architecture between 1960 and 1965. There were signs of an economic downturn after 1965, but the progression in architecture was continuing. At the same time political decisions triggered the industrialisation of building construction, along with the setting-up of pre-fabricated building factories and the construction of buildings based on mechanical principles. Significant achievements were also made in 60s' architecture, demonstrating a sign of openness towards Western-European processes. The centre in Salgótarján, inspired by Le Corbusier's concrete beam architecture, came to realisation around the time of the 1964 Tokyo Summer Games for which the architect Kenzo Tange built two stadiums, reinforcing the timeliness of the Hungarian efforts.

It is well demonstrated in the first 10 years of the journal's history that 1968 was a period of change between different eras. The journal worked well with the contents it covered until its profusion of content prevented us from realising our fundamental objectives.

The academic scientific research received more emphasis between 1957 and 1965 in the areas of those committees that received additional opportunities for publishing. Publishing conferences that dealt with the specific problems of the era and were important for the government were of utmost significance, as the summaries helped with the completion of the projects. In the field of Building Sciences The conference in the matter of prefabrication of 1957 appeared as material of the sessions of Civil Engineering Section and Surface Construction Section filling in the whole number (Vol. II. No. 1.). The National Thoroughfare Conference was published in the field of the Committee on Transport Sciences in the No. 2., the Conference on History of 
Architecture and Monuments in the No. 3-4. and The Conference of Industrial Constructions in the Vol. VI. No. 2. Material of international significance of the 2nd Conference for History of Architecture and Protection of Monuments appeared in the Vol. IV. No. 3., while the other issues of the I-VI. Volumes also published important articles, review materials and book reviews from different disciplines. They included such important topics as A new theory of the continuous reinforced-concrete girders (Vol. I. No. 3-4.), Principles of regional planning in Hungary (Vol. IV. No. 1-2.), Guiding principles for the protection of monument-complexes (Vol. IV. No. 3.), Traffic in the big cities (Vol. IV. No. 4.), Railway-architecture in Europe (Vol. V. No. 1-2.), Architectural survey of modern urbanism (Vol. V. No. 3.), The "Bauhaus" idea and reality, and The "Bauhaus" and its workshops (Vol. VI. No. 4.).

I do not mention the engineering scientific fields' important articles that are mainly dealing with laboratory findings, I would only like to raise attention to the academic scientific reports and reviews with a view to mention the development of topics in our scientific field.

The developments that took place in the 1960s can be easily traced in the contents of Vol. VII-XII., which we summarised in the jubilee issue Repertory (2007) as a retrospection of the past (ÉÉT Vol. 35. No. 3-4.). From 1965 two of us were working on preparing the journals. We had time to pay more attention thus enabling the illustrations to reach higher standards.

Important conference materials of this era are Conference on the "Development of Historical City Centres - Problems of Architectural History" and the 3rd Conference for History of Architecture and Protection of Monuments in the same issue (Vol. VIII. No. 1-2.), and International Work-Meeting on Protection of Historic Buildings of the Hungarian Academy of Sciences (Vol. X. No. 1.). As the Debates within the field of Urban Studies for PhD academics (Vol. VI. No. 4.) became more regular, we started publishing the reports from these debates and in turn the Urban Studies Committee become more active. The last issue of the journal Épités- és Közlekedéstudományi Közlemények was published in 1968 (Vol. XII. No. 3-4.).

I need to mention at this early stage that even though we published the journal in low quantities they were present at the important new state institutions and fulfilled the demand of the time. The interests of the readers and editors covered a wide range of scientific fields but the publication completely fulfilled its scientific development mission. During the journal's 12-year operation an opinion was formed about narrowing down its scientific fields and concentrating their resources on certain areas. By the end of the 1960s the industrial background and the directive planning office system was created and the institutional system behind scientific research became significantly stronger. The Section of Engineering Sciences of the Hungarian Academy of Sciences could reorganise its journals, consequently creating a new one called Épités- Épitészettudomány which was founded on the editorship of the Épitésés Közlekedéstudományi Közlemények. 


\section{START AND PERIODS \\ OF THE JOURNAL ÉPÍTÉS- ÉPÍTÉSZETTUDOMÁNY}

The first issue of the Épités- Épitészettudomány (Architectonics and Architecture, Vol. I. No. 1-2.) was published with the following bibliographical data so the new era of the journal started:

Épités-Épitészettudomány. Bulletin of the Section of Engineering Sciences of the Hungarian Academy of Sciences. Editor: Máté Major. Editorial board: László Gábor, Sándor Kaliszky, Árpád Kézdy, Máté Major, Imre Perényi. Technical editors: Tiborné Horváth, Ferenc Vámossy. Vol. I. No. 1-2. Akadémiai Kiadó, Budapest 1969.

László Gábor's name was written in a black frame in 1981, signifying his passing, and by 1983 his name was left off of the editorial board. In 1984 Árpád Kézdy's name received a black frame and in 1985 his name was also missing. The editorial board was then: Sándor Kaliszky, Máté Major, Imre Perényi. In 1986 Máté Major's name was in a black frame. The new bibliographical data:

Épités-Épitészettudomány. Bulletin of the Section of Engineering Sciences of the Hungarian Academy of Sciences. Editor: János Szabó. Editorial board: Sándor Kaliszky, Imre Perényi, János Szabó, Ferenc Vámossy. Technical editors: Edith Horváthné Sipos, Ferenc Vámossy. Vol. XIX. No. 1-2. Akadémiai Kiadó, Budapest 1987-1988.

New changes in 2000:

Épités- Épitészettudomány. Bulletin of the Section of Engineering Sciences of the Hungarian Academy of Sciences. Editor-in-Chief: János Szabó. Editor: Ferenc Vámossy. Editorial board: Sándor Kaliszky, Tamás Meggyesi, János Szabó, Ferenc Vámossy. Technical editors: Edith Horváthné Sipos, Ágnes Gy. Balogh. Vol. XXVIII. No. 1-4. Akadémiai Kiadó, Budapest 1999-2000.

After this issue appeared „,The Announcement of Épités - Épitészettudomány on renewal, published 15 September 2000" and the following bibliographical data:

Épités-Épitészettudomány. Bulletin of the Section of Engineering Sciences of the Hungarian Academy of Sciences. Editor-in-Chief: János Szabó. Editor: Ferenc Vámossy. Editorial board: Gábor Domokos, Zsolt Gáspár, Sándor Kaliszky, Tamás Meggyesi, János Szabó, Ferenc Vámossy. Technical editors: Edith Horváthné Sipos, Ágnes Gy. Balogh. Vol. XXIX. No. 1-2. Akadémiai Kiadó, Budapest 2001.

In Vol. 34. No. 1-2, 2006 the above list of names were not changed. The age of digital culture had already appeared in 2000. A bibliographical text explaining the scientific field the journal deals with has always been printed on the inside cover of the publication. The journal publishes studies in the fields of building and architecture that are supported by the Committees on Theoretical and Applied Mechanics, History of Architecture and Monuments, Architecture as well as on Urban Studies all of the Department of Engineering Sciences of the Hungarian Academy of Sciences. The content of the wording has been the same from the start, but the names of the different committees have changed a number of times, both in the case of the Committee on History and Theory of Architecture and in the fields of Engineering Science. 
In this new period of state socialism the characteristics of society and economy changed in the same way as the modernisation's, or the already formed construction industry along with architecture. The "Goulash Communism", which was the envy of many socialist countries, transformed architecture in a similar way to other parts of society.

The standstill in the second half of 1960 could also be felt in the architecture industry and led to the search for a new mechanism. The economic reforms' well-intentioned initiatives brought a bit of an upturn in the early 70 s and resulted in a short recovery of the economy. The suppression of the 1974 reform, the disparagement of the results of the American and European realignment after the international economic crises, and further attempts to shut everything out led to an additional economic downturn and a state of long recession which in 1989 led to the fall of the dictatorial global system.

The reform between 1968 and 1974 naturally created opportunities for information gathering within the architecture industry. The Danish Larsen-Nielsen system appears within the industrialisation of construction. This was later replaced during the unification of the French originated panel technology by the simplified soviet panel manufacturing and standardisation practice. The lightweight construction program still demanded information gathering from the west. Some professional relations became international and the objective was to follow the most advanced standards. This is only forgotten when reforms are held back. It is no longer possible to put a stop to efforts like the domestic organic architecture or new European trends. This is the reason why our architecture was more colourful after 1978 but soon the 80s' recession came and the designer architects began to vanish. Naturally, the year 1989 began a period of change.

As the processes only relate to the research fields indirectly, their effects are barely perceptible in the journal directly but the more significant efforts were published in the articles and review materials. In the summary that contains the journal's internal revision, prepared for the Hungarian Academy of Sciences and its publishing house Akadémiai Kiadó, published on the 15th of September, 2000. This publication was indicative of the changes ahead. This was also brought out in Vol. 35, the jubilee issue of Repertory, in 2007 and on page 53 we made the following statement:

"The journal Épités - Épitészettudomány (Architectonics and Architecture) has been an internationally acknowledged document of the sciences of Hungarian architectonics and architectural culture since 1969 (...) Our journal has also suffered the difficulties involved in the transformation of scientific and research activities in the last decade. The institutional framework of professional research has changed and has become more limited, the tasks of university research laboratories have increased, a new system of university doctoral formation and qualification has been introduced, and accredited scientific programs have been finalised. This entailed the enlivening of university research, and the necessity of renewal and a change in role became clear." 
We used this justification to state our intentions for the journal's renewal:

„As a result we wish to renew the journal from 2001, broadening the group of authors and readers. We wish to renew our publication as one that continues to be the most important, regularly published document on research with a fast turnaround time, a professional journal setting the highest professional and scientific standards, keeping its proofed and edited character, providing the bounds for high-lighting important research projects in progress. We also wish to provide teachers carrying out scientific activities and young researchers pursuing postgraduate studies, as well as young scientists applying for the $\mathrm{PhD}$ process at the Faculties of Civil Engineering and Architecture and sister institutions with the opportunity of publishing their results in the journal. In addition to the fields of architectonics and applied mechanics, research in the history and theories of architecture, historical sites and buildings, we are also looking forward to publishing scientific results of planning development and urban design.

In the future we wish to fully satisfy the communication requirements of the professional and scientific intellectual scene of our field. By renewing editing we wish to facilitate a surge in scientific research that has been troubled recently."

In the jubilee issue Repertory (1957-2007) (Vol. 35. No. 3-4.) four scientists summarised their opinions about the 50 years of the journal: Ernő Marosi: Art history in the 47 volumes during the fifty years of Épités - Épitészettudomány (Architectonics and Architecture), earlier Épités- és Közlekedéstudományi Közlemények (Publications in Building and Transport Sciences); Zsolt Gáspár: Publications in Építés - Építészettudomány (Architectonics and Architecture) in the last 50 years from the viewpoint of mechanics; József Finta: On the 50 years of Épités Épitészettudomány (Architectonics and Architecture) or "history of ideas" of our architecture; Tamás Meggyesi: Changes in topics and views of the town planning profession throughout the 50 years.

These four studies paint a very sensitive picture of the past fifty years of the journal and say a lot more about the journal's past, the significance of its past and about our architectural culture than my current piece. Zsolt Gáspár for example mentions 145 studies among the more than 100 publications from 26 academics within his field.

Due to their importance I will be summarising and quoting significant findings later on to give a clear picture about the work carried out in the past fifty years.

\section{ABOUT THE MATERIALS PUBLISHED BY ÉÉT AND EDITORIAL PROBLEMS}

The conference topics and collections of material that filled full issues describe well the internal development and nature of the research taking place in the fields of construction, applied mechanics, architecture, history of architecture and monuments between 1969 and 2007. The Épités - Épitészettudomány's topic changes, as well as the development and broadening of the research areas are well demonstrated by the 
number of significant events, collection of materials relating to celebrated individuals and the career reviews of exceptional scientists.

Forty art historians congratulated to Anna Zádor with their architectural historical essays (Vol. V. No. 3-4. 1976) The conference Architectural problems in building industrialization was the subject of the Vol. IX. No. 1. (1977), and Festschrifts was published to Dezső Dercsényi (Vol. XII. No. 1-4. 1980), to Géza Entz (Vol. XV. No. 1-4. 1983) and to Jenö Rados (Vol. XVII. No. 1-2. 1985). These important conferences appeared in the next decades: Lectures at the joint session of the Section of Technical Sciences of the Hungarian Academy of Sciences and the Technical University of Budapest in commemoration of professors Pál Csonka and Imre Korányi on June 26, 1986 (Vol. XIX. No. 3-4. 1987-1988), Open meeting on "Morals and meaning of traditionalism" of the Committee of History and Theory of Architecture of the Hungarian Academy of Sciences on October 6, 1987 (Vol. XX. No. 1-2. 1989), "Tradition and intuition" scientific session of the Institute of History and Theory of Architecture, Technical University of Budapest, December 13-14, 1990 (Vol. XXII. No. 3-4. 1991), Scientific session commemorating the 150th anniversary of birth of János Feketeházy, May 12, 1992 (Vol. XXIII. No. 3-4. 19921993), Scale of values, Authenticity and originality in monuments preservation. Lectures and discussion at the OMVH-ICOMOS Conference, October 26, 1994 (Vol. XXV. No. 1-2. 1995), László Gábor memorial session Lectures and contributions of the programme of the Commission of Architectural Science of the Hungarian Academy of Sciences on 23rd November 2000 (Vol. XXIX. No. 1-2. 2001), Commemoration on Máté Major's 100th anniversary. Conference of the Budapest University of Technology and Economics Department for History of Architecture and of Monument on 11th September 2004 (Vol. XXXIII. No. 1-2. 2005). In the same issue Surveying and valuating the scientific career of György Kunszt. Lectures delivered on the festive, open session organized by the Development for Technology of the Hungarian Academy of Sciences held on 9th November 2004 was published. Each period and intention at the time has its own controversies, and in the latter case the celebrated author is effectively compiling the materials covered during his career.

Special mention must be made of the next conferences: Budapest Technical University education of architectural history celebrating its 140th anniversary. Lectures of the festive session on 22nd April 2010 (Vol. 38. No. 3-4. 2010), Structure - Texture - Facture. Materiality and digital technology in the architecture. Lectures of the conference on 12th of May 2011 (Vol. 39. No. 3-4. 2011), Conference in memory of Tamás Guzsik. Lectures from the conference on 6-7 December 2012 (Vol. 41. No. 3-4. 2013) and Conference of architectural historians and researchers in memory of Zoltán Szentkirályi. Lectures of the conference on 6-7 February 2014 (Vol. 42. No. 3-4.).

It is not possible to summarise the important topics when reviewing such a long period, as even the Repertory, that summarises the past 50 years, included 695 authors and the number of authors' work is over 1000 pieces. At the time of the EKTK there were already 316 authors, out of whom 47 were foreign guests from socialist 
countries at the different conferences. 104 new authors joined the journal's research group in the last 10 years and the number of independent publications exceeded 1500 . The researchable topics covered in their fields of science in the 58 volumes of the two different journals are incredibly rich.

In search of answers to the questions on what the journal was able to accomplish, and how and to what extent did it achieve its role in the Hungarian scientific research set out by the founding members, we cannot come up with a confident answer. To what extent did those objectives which we set out after the socioeconomic changes in 2000 with the option for renewal materialise? What did we do in the last 17 years within our area of responsibility in order to review and improve our special subject topics and to make them more successful? Did we manage to support the doctorate training, to put important subjects on the agenda and duly succeed in fulfilling the task presented to us by our field's professional-scientific intellectual aspects?

Despite our best intentions, the number of printed copies fell, and their distribution remained in the background in comparison to computerised communication. It is certainly true that in scientific research the materials have to be kept and made accessible for a long time.

The arrival of the new and promising digital culture made our journal digitally available, giving us new virtual opportunities. We have to press home a point here a bit longer. It is founded on a misconception that the 3D imagery with its virtual abilities can be sustained for a long time in comparison to the known characteristics of knowledge held in a printed format. With the possession of the machine culture's virtual opportunities the intention to keep knowledge for long periods has faded. I know from my own experience that if you only store something digitally on one server it can lead to the loss of that acquired knowledge. I worked on a study for 10 years titled Architectural culture in Hungary, requested by the METESZ, which was published on the World Wide Web in 1998 amongst ten other topics being part of the Hungarian History of Technology Guide. 12 years later it was removed from the web and disappeared, even though its messages are still valid today.

Virtuality therefore cannot be overrated, even though it is the definition of the Idegen szavak és kifejezések szótára (Dictionary of foreign words and expressions) (Akadémiai Kiadó, Budapest 1994). According to this: "virtual lat 1. ostensible, imagined, not real. 2. existing as a possibility, implied within. 3. ostensible, a virtual image". The same way as a 3D imagery is not the physical reality.

Our material also has to be valid for a long time. This prompted the editors to create the Repertory issue, in which the table of contents and the editors' index helped to speed up the reader's search. Following the publication of this special issue, we received a Merit Award by the Hungarian Academy of Sciences and the Akadémiai Kiadó in 2008 in recognition of the journal's scientific achievements. 
By all means, we need to adapt to the digital world but also have to maintain printed distribution. In other respects, I believe we achieved our goals. We never rejected any adequate quality manuscripts and strived to publish them as soon as possible. Thus complying with the requirements of doctorate training. We help with the cooperation between the supervisors and $\mathrm{PhD}$ students in both the engineering and architecture courses. In this respect the editorial board gives a lot of assistance and there is great cooperation within the editorial team. In the past 15 years, I believe, we again satisfactorily fulfilled the commitments that we jointly took on.

I do not want to say that in the editorial work we never had any misunderstandings, arguments, controversy, obtuseness, dismay through tiredness, uncertainty, occasional inner tension or other problems affecting efficiency, but I am convinced that any conflicts were smoothed out by the desire to cooperate.

An important aspect of editing is to choose which subjects we want to cover and to assist the authors with writing up their themes. It is in the very nature of the journal, and also coincides with the requirements of the doctorate training, that the writing up of the theme is based on the academic level of interest. This poses an important task for the supervisor, the proofreader and the editors.

The nature of the journal also sets requirements, i.e. the length of a standalone journal that is suitable for publishing. Dividing up topics that should be covered in a book, or expositions that belong to an ordinary scientific journal would both be wrong. We cannot accept articles that are too long, low quality illustrations or if their wording is not suitable for an academic journal. We can only keep to these requirements if all stakeholders are in agreement with them.

\section{THE MOST IMPORTANT CONCLUSIONS FROM THE PAST 50 YEARS' REVIEWS}

Let's go back to the four author's conclusions in the jubilee issue, Repertory.

Ernő Marosi, being an external judge, stated that scientific journals often get to their fifty-year continuance. This period is equivalent to three scientific generations thus it is often a source of professional remembrance and a source of science history. Marosi raises the unsolved issue of making digital publications, because the journals also need to fulfil an archiving role. The journal's volumes covering wider subject areas under the name $\dot{E} K T K$ are an important source of art history. Its publications highlight the technical and theoretical backgrounds of the period's architecture. Marosi demonstrates these through examples such as the Árpád-bridge in Old Buda or the continuous jointed rail. He stresses the importance of Frigyes Pogány and Pál Granasztói's studies on urban history and town planning, than emphasises the importance of the publications presenting the period's technical results, from the Bauxit concrete and canvas tent to the conference titled the Morals and meaning of traditionalism, all of which helped with broadening reader's perspectives. 
Most of the time the two journals were an important forum on art history publications. The authors are analysing whether architecture should be classed as fine art, noting that the protection of monuments is one of the most important sources of art history. Marosi highlights century-long tradition of teaching architectural history as well as theory of architecture at the Budapest Polytechnical University mentioning names of Imre Steindl, Kálmán and Géza Lux, Károly Csányi, József Csemegi, from the newer generation István Czagány, Erzsébet Cs. Tompos, Jenő Major, Tamás Guzsik, Alajos Sódor, in preservation of historical monuments László Gerö, Béla Borsos, Dénes Komárik, István Bibó, in theory of architecture Gyula Hajnóczi, Zoltán Szentkirályi, Margit B. Szücs, Gábor Hajnóczi.

From the 1960s the Committee on History and Theory of Architecture of the Hungarian Academy of Sciences (MTA) worked on the preparation of a major reference book on architecture history (László Vargha: History of the Hungarian architecture ÉÉT Vol. II. 1970). This topic was directed by the Subcommittee on History of Architecture (the task was later taken over by the MTA Research Institute of Art History). The general theme took shape at major conferences.

Important review was published by László Gerevich entitled Medieval royal workshop in the 14th century and the advanced Gothic art from the first Conference on history of architecture and monuments (EKTK Vol. II. 1958). Likewise significant lectures were presented in the 2nd conference: Anna Zádor: The events in Europe preceding the development of the Classicism in Hungary and József Csemegi: Architecture-historical problems of the central churches in Central Europe of the Romanesque Period (EKTK Vol. IV. 1960). In the 3rd conference it was relevant: Dezsö Dercsényi: Advance towards a Central European history of architecture (ÉKTK Vol. VIII. 1964).

Problems of methodology and approach of monument preservation were discussed in the International work-meeting on protection of historic buildings of the Hungarian Academy of Sciences in 1964 (EKKTK Vol. X. 1966). According to Marosi these publications had attitude-changing and school-founding merits. It also became an important forum for young scholars of architectural historical research. Several issues were dedicated as Festschrifts to art historians. Marosi also mentions that the journals specialising in the protection of monuments changed their themes in the 1970-1980s and the monument protection topics were replaced by publications on the preserving and chemical industry. He noticed these new topics: Bauhaus (ÉÉT Vol. IX. 1977), Hungarian form aspirations (ÉÉT Vol. XI. 1979), Discussions about national architecture (ÉÉT Vol. XX. 1989, Vol. XXIV. 1994), Farkas Molnár (ÉÉT Vol. XX. 1998), Morals and meaning of traditionalism (ÉÉT Vol. XX. 1989), Tradition and intuition (ÉÉT Vol. XXII. 1991), Scale of values, authenticity and originality in monuments preservation (ÉÉT Vol. XXV. 1995), Inspiration (ÉÉT Vol. XXIX. 2001), Making and work of art in the realm of built environment (ÉET Vol. XXVIII. 1999-2000).

In the introductory of his analysis Zsolt Gáspár states that the journal Épités Épitészettudomány and its predecessor in title have a significant place among the 
publications in civil engineering and architecture. To demonstrate this it should be noted that in the last 50 years 26 members of the Hungarian Academy of Sciences (or those later becoming members) had publications in the journal: János Bogárdi, Elemér Bölcskei, György Csanádi, Pál Csonka, Gábor Domokos, József Finta, Zsolt Gáspár, László Gerevich, Gyula Hajnóczi, Ottó Halász, Ottó Haszpra, Sándor Kaliszky, Árpád Kézdi, László Kollár, Lajos Kollár, György Kovács, Márta Kurutzné Kovács, Ernő Marosi, Győző Mihailich, Pál Michelberger, Emil Mosonyi, István Páczelt, László Palotás, János Szabó, Károly Széchy and Tibor Tarnai.

In what follows Gáspár only reviews articles relating to mechanics of solids. In the first year several authors dealt with continuous reinforced concrete beams. In the second year P. Csonka (1958) gave approximative formulas for the stability analysis of precast structural elements, also providing error estimations from simplifications. From 1959 papers started appearing in the journal about statical and stability analysis of shells and shell arches, which later got incorporated in several popular books (Kollár, 1973; Kollár and Dulácska, 1975; Csonka, 1987).

Even the prismatic bar with a straight axis is difficult to analyse if under torsion (L. Palotás, 1959), or if the boundary conditions are special (L. Lipták, 1960), or if pre-stressed (B. Goschy, Gy. Balázs, 1961). S. Kaliszky (1961) provided formulas for the loadbearing of concrete and reinforced concrete walls, while B. Andor and Gy. Iványi (1963) for bent reinforced concrete structures.

Solutions for problems in mechanics had been sought using analytical methods before but from 1965 papers were published using matrix calculations or numerical methods. E. Béres (1965) showed the analysis of grids, while J. Szabó (1965) the calculation of state variables of cable nets by non-linear equation systems. B. Roller (1966) also studied cable roofs though using differential equations. Gy. Vértes (1968) published the first paper in dynamics regarding natural frequencies of vibration of high-rise buildings.

It is not possible to sum up the ÉÉT's (1969-2006) summary in a shorter version than the eight pages written by Zsolt Gáspár published in the Repertory. I can't undertake that here.

As Zsolt Gáspár writes: "We can declare that this 50-year-old journal has had a very important place in the Hungarian literature of solid mechanics. Solutions have been provided for statical, dynamical, and stability problems for several reinforced concrete, steel, timber, and membrane structures, and moreover, interesting theoretical questions have also been studied. Many authors published one or two important theses of their later dissertations, overviews of inaugural lectures in the Academy have also been published here. We have already mentioned before that several papers in the journal got included later in popular books from the authors. To support this statement we note that a book on stability problems by many authors edited by L. Kollár [1999] cites 17 papers from the celebrated journal: I. Bódi (1986), E. Dulácska (1963), E. Dulácska and I. Kovács (1971), Zs. Gáspár (1977, 1984), O. Halász and M. Iványi (1978), L. Kollár (1960, 1961, 1962, 1963, 1984), L. Kollár and I. Bódi (1984), L. Lipták (1960), Gy. Popper (1978), T. Tarnai (1979, 1984), K. Zalka (1982).” 
It was clear from Gáspár's review that during the time of the two journals' existence, authors from all different science fields reached the areas of mechanics in Hungary through our publishing of their studies on topics such as: simple analytical and numerical calculations and computer advancement, the arrival of new methods in relation to non-linear material and/or physical methods in all science fields, the use of catastrophe theory, structures' sizing processes, stability of beam structures, the surface area of canvas structures, biomechanics, and technologies on in-situ reinforced concrete structures through panel or shell construction technologies, just to name a few.

József Finta states that his career in architecture almost stretches back to the time of the foundation of the journal. The period of the 1960s 1970s, the time when huge building estates, urban texture consisting of blocks of flats, and over-dimensioned industrial construction projects were built, many achievements of our architecture and construction sector, the technical, technological and management modernization of construction, the development and operation of its special institutional system and simultaneously the role it played in CIB (Construction Industry Board) cannot be questioned.

These modernization processes unfolding in Hungary, and the development of the professional research performed in the background, the effort put into organization and the system of conferences, the general advancement of the Hungarian scientific life and activities, are reflected along with their values and controversies in the publication indices spanning these fifty years. The spiritual history of our architecture can also be drawn in its entirety from these.

Despite a latitude encompassing everything negative, and clamping it down, Hungarian architecture is not at all as poor and provincial as alleged by some of its critics.

Writings once (and even today) touching upon the topic of the protection of historic monuments as well as excavations and restorations of historical sites and buildings in Hungary merit special mention. This was where members of the great generation (László Gerő, Jenő Rados, Dezső Dercsényi, Géza Entz, Miklós Horler, Frigyes Pogány and others), unquestionably elevating the protection of historic monuments in Hungary to a leading European level, often published their writings. Nor can we keep quiet about those publications that presented and analyzed topics related to the building industry, the highly developed Hungarian pre-fabrication industry, problems in statics, construction technologies, as well as material and quality inspections at a high scientific level.

Finta found it damaging that the journal could not get a more exciting and marketable form and take on the role of the mission of expat propaganda. There is an important intellectual desire in the operation of the journal that put the common foundation of urban design and architectural theory criticism - and design theory, the institutional development of the methodology of architectural design - in the centre from an architectonics point of view in the past as well. Architecture and architectonics are an increasingly intertwined units. Hungarian and international research needs to be 
relied on more and more (from the aspects of construction, use of materials, energetics, and even a social sense).

Tamás Meggyesi began his review with this statement: "Fifty years is a very short time as covering a single life span, and very long compared to the stormy historical changes influencing not only the topics but the attitudes of scientific approach - that relates particularly to urbanism and town planning. Western 'municipal socialism' and technocracy had its parallel with the ideologically influenced optimistic belief in the future of socialism in East Europe. Both had to face the un-sustainability of the system, but - with a 15-year delay - it has led to a radical political change in the East."

The articles may be arranged in at least 5 groups according to their topics. The studies in the first group are characterised by an ideological commitment deeply influenced by the official view of urban and regional planning (essays of Imre Perényi, Kálmán Faragó, György Gerle, Péter Novák, Károly Perczel, György Köszegfalvy, Pál Teleki, István Kiss, Tibor Mendöl). Studies of the second group are deeply engaged in an academic debate about the concept and relations of "The Science of Settlements", represented by a new Committee in the Hungarian Academy of Sciences (János Brenner, Pál Granasztói, István Valló, Ferenc Harrer, Ferenc Vidor). The studies in the third group deal with problems of normativity, closely related to the state sponsored social housing prevailing the building activity of the 1960s and 1970s (János Brenner, Tibor Zsitva, Géza Jándy, Jolán Bakai and Tamás Meggyesi's early publications). The studies relating to the history of urban development and its outcomes for the reconstruction of the core in historical cities may form the fourth group (György Korompay, Pál Granasztói, Jenő Major, Gábor Preisich, Imre Perényi, Frigyes Pogány, Gyula Hajnóczi, Zoltán Szentkirályi, András Román), and the fifth is characterised by articles representing joint- and partner professions as civic design, urban geography or landscape architecture.

According to Meggyessy there is a gap in the fields of self-governance and property development, and in the area that specialises in the relationship between the two areas. He also mentions that taking up the names "Architectonics" and "Architecture" in town planning, only very slowly became part of the identity, and turned into a generational problem. The "elderly" (the urban planners) found it hard to give up on the priorities of controlling the two-dimensional configuration while the "young" (the architects) no longer believed in the omnipotence of rules. The Committee on Urban Studies which used to be able to fill an issue with their publications $(1965,1976)$ went silent. They would rather be in the same league with regional and geographical science.

The articles after 2000 engaged not too much with the basically different political, economic and social situation, but seem to give up the formal discussions in theoretical questions, at the same time getting more interested in renewing the lost relations with architecture and urban design. 


\section{ABOUT PERSONAL RESPONSIBILITY}

I was not irresponsible when citing the four studies contemplating the past 50 years even though Zsolt Gáspár and Tamás Meggyesi, being part of the editorial board, were biased against the journal. As they worked in the editorship they felt the burden of some of the responsibilities. I cannot recall any open attacks or even whispering criticism about the journal in this 50 year period that I could have regarded as negative. As all members of the editorship have been considered to be part of the journal's community and the publication is the result of our joint efforts I accept the cited words of acknowledgement with clear conscience.

It has been different in the past ten years as in the last year we received very harsh criticism on the journal from the Scopus Evaluation Committee, the most important competent authority. When I communicated my intention to retire and requested the Academy to make me the deputy-editor four years ago, perhaps I withdrew from active work more than I should have. We might have published articles that were too long and did not contain a lot of new information. The Committee criticized the published issues between 2013 and 2015. I did not agree with the judgement fully but took my part of the responsibility for it at the editorial board meeting discussing the issues. We are currently looking at ways to avoid making the same mistakes and shortcomings. Among others the following issues have also been raised: English addition to the journal's title, controlling linguistic accuracy, making changes within the editorial board, defining the journal's mission, rethinking the special fields, carrying out the digital tasks consistently and the use of an electric copy-editor system. As all this comes with changes in personnel, my successors have to contemplate and execute their decision with joint responsibility.

My personal responsibilities are outlined below: It has been a huge experience and opportunity for me to be part of the editorial work and the editorships' operations since 1958. I have been working closely with the editorial board, people cooperating in the technical editing and the journal's authors and proofreaders. I always had a sense of responsibility in accordance with the different tasks given by the editors and editors-in-chiefs. I made all efforts to cooperate and work in harmony. I went through a difficult period when my chief editor, János Szabó, suffered from a long illness and I had to take on additional work. Perhaps I made a mistake at the time when, with permission from the Academy, I withdrew too much from the daily work.

Looking back over my career, I would be the first to say, that as far as I remember, I never accepted scripts forced on me for publishing or put people at advantage or disadvantage. I always believed that information gathering and follow-ups have to come before the editorial work in order to keep the journal at a consistently high standard. The journal needs to reflect the high standards of academic research and in order to achieve this we have to fend off all external pressures. I regarded this to be the most important trait of the editorial function and it is rather painful if we feel that we made this mistake or let other people make it. 
I feel I was right in regarding the support of both university faculties' activities equally important, as well as the representation and validation of both of their viewpoints and the formation of the faculties by our publications. Throughout my carrier I had to keep up with developments and changes within both scientific fields, pay attention to the main subject areas and implement those in the journals and understand the significance of the publications. All this needs to drive the job of the editor from choosing the proofreader to the most scrupulous selection of the illustration materials. At the same time this is also where the source of pleasure is. This is why it was worth taking on this task which has meant so much to me over the last 60 years. I spent about a sixth of my working time on the journal.

Of my fate, together with many others in this job, I can say, in the words of the poet:

"Thank you, life, for thy blessings

- this has been great joy, yea, the Work of Men!"

(Mihály Vörösmarty: Thoughts in the library) 